\title{
Parental Views on School Lunches: Insights into Childhood Obesity
}

\author{
ZOEY VERDUN \\ University of Victoria \\ zverdun@uvic.ca
}

\begin{abstract}
The obesity epidemic constitutes a large and growing share of public health spending. This paper investigates parental views on providing healthy food choices in school lunches in an attempt to contribute to a better understanding of the parents' role in addressing childhood overweight. I created a survey that was circulated at an elementary school in Victoria, B.C. The results are discussed using a standard microeconomic framework in which parental choices of their children's lunches depend on their views ("utility") as well as the restrictions they face. My results suggest that parents perceive price not to be a major factor in the decision to include fruits or vegetables in their child(ren)'s school lunch. The reason provided most frequently by parents for not including fruits or vegetables every day is the expectation that their child(ren) would refuse to eat them, or have too little time at school to eat them. Some parents also mention preparation time as a reason for not including fruits and vegetables.
\end{abstract}

Keywords: Children; health; obesity; overweight; fruits and vegetables; parents; school lunches

"This article is based on my Honour's thesis. I am grateful to my parents for their support throughout the writing of that thesis. Furthermore, I acknowledge the Jamie Cassels Undergraduate Research Award that financed part of the research. Finally, I would like to thank Dan Lett, editor, as well as the anonymous referees of the Arbutus Review for their helpful comments and suggestions. 


\section{INTRODUCTION}

$\mathrm{L}$ EVELS OF OBESITY among children and adolescents have tripled over the last thirty years (Evans, Finkelstein, Kamerow \& Renaud, 2005, 26). Obesity is understood to be "a condition in which someone is too fat in a way that is dangerous for their health" (Macmillan dictionary, 2014). The World Health Organization (WHO) considers children obese if they are two standard deviations away from the average and they are considered overweight if they are one standard deviation away (WHO, 2013). The causes of obesity are many, including genetics, social norms around weight, physical activity, and food quality and quantity. Childhood obesity differs from "adult" obesity in that adults make their own choices and are responsible for their own health, including what they eat and their physical activity. By contrast, children do not determine on their own what they eat or their level of fitness. Rather their parents, guardians, and schools have a large influence on food intake and activity levels (henceforth, when I refer to "parents," I am referring to both parents and guardians). As a result, childhood obesity has an extra layer of complexity compared to adult obesity.

This article is based on a larger research project reported in my Honours thesis that focuses on the food quality dimension of childhood obesity (Verdun, 2014). It poses the following research question: what factors impact the choices of parents regarding their children's school lunches? To analyze this question I created a survey, which I circulated among the parents of children of a local elementary school. This survey included questions about parents' views on (1) school programs about healthy choices; (2) taxing "unhealthy" foods and subsidizing "healthy" foods; (3) a lunch program provided by the school's Parents Advisory Council (PAC); and on (4) the lunches parents packed for their children, the restrictions parents faced, and their perceptions on childhood "overweight." In the survey I used the term "overweightness" instead of "obesity" since the latter may be considered to have negative connotations (Jancin, 2012). I collected fiftyseven responses to the survey. 
There is a vast scholarly literature on childhood obesity. For the purpose of this study I have subdivided the relevant literature into four broad areas, which I will review in Section 2: (1) taxing unhealthy foods and subsidizing healthy foods; (2) the provision of food in school (such as school lunch programs); (3) health education and physical activity in schools; and (4) the debate surrounding monitoring of obesity in schools.

Canadian data that connects food quality or food pricing to obesity in children is absent. Data exists on the United States (US) but may not transfer adequately to the Canadian context. However, a number of insights from research using US data do apply. For instance, parents have to make trade-offs when determining what to pack in their child(ren)'s lunch. Furthermore, there is very little data on parental views on school lunches. It is important to learn about parental views, as these should provide us insights into parents' role in providing children with healthy lunches. Thus, for this study, I collected my own small sample of data. I surveyed parents whose child(ren) attend(s) one local elementary school. I inquired into what influences them in providing healthy lunches to their children. Earlier studies on childhood obesity that examine parents' perceptions, have used a series of questions (Evans et al., 2005, p. 30). I have adapted some of these questions and created others (see Appendix A1 for the full list of my questions).

I analyzed the responses to the survey using a standard microeconomic framework in which parental choices of their children's lunches depend on their views ("utility") as well as the restrictions they face. The restrictions considered differ depending on the actual survey question analyzed, but include the idea that parents do not always have leverage over what part of the lunch their children will actually eat at school - as in a Principal-Agent setting, where parents are the Principal and children the Agents. In this context it could be that parents are more interested than their children to see that they have a serving of fruits and vegetables in their lunch every day. Other possible restrictions could be money, time (including but not limited to preparation time, consumption time at school, and time available to buy 
fresh produce), and knowledge.

Statistical significance is often an issue in small samples. Nevertheless I identify the following patterns in my sample: (1) parents who perceive childhood overweight to be a greater issue in the school are more willing to support school programs that provide health education and physical activities; (2) parents who perceive childhood overweight to be a greater issue in British Columbia are more willing to support subsidizing fruits and vegetables; (3) parents are less likely to provide fruits and vegetables in the lunch when they face restrictions (such as lack of time, child refusal and/or peer pressure); (4) parents indicate the cost of fruits and vegetables is not one such restriction; and (5) parents who perceive childhood overweight in their family to be less of an issue than other parents are more willing to support making PAC lunches healthier. In economics we look at the cost of goods and how it affects consumption. The parents who participated in the survey support increasing the costs so as to ensure their children obtain healthier lunches (i.e. increased content of fruits and vegetables).

This article is structured as follows: I start with a literature review, methodology and survey design. I then present my findings followed by a discussion. Finally, I summarize my main findings and offer some suggestions for future research.

\section{LiterATURE REVIEW}

Food production has evolved over time. Cutler et al. (2003) look at some of the changes as a result of new technologies. These changes have led to mass production of food, pre-packaged food (including snacks), and decreased time in preparing food. They find that the increase in calories comes from an increase in the number of snacks people eat, not from eating more at each meal or snack. This increase in the frequency of meals is made possible by the decreased cost both in terms of time and money of making meals to eat. 


\section{Taxes and subsidies}

In economics the behaviour of the consumer is influenced by price. Therefore governments can encourage or discourage the consumer by decreasing or increasing the price of certain goods: subsidies and taxes. How much a consumer changes his or her behaviour depends on his or her price sensitivity and the price-elasticity of the good. In layman's terms, if a good is price-elastic a person will change his or her purchasing behaviour when the price of the good changes, whereas if a good is price-inelastic, a person will buy the good almost regardless of the (change in) price. Governments use the policy instrument of taxation to discourage consumption (or overconsumption) of goods that are viewed to have negative externalities to society (for example, the increased cost of obesity on the medical system funded by the government). Regarding the taxation of unhealthy food, there has been discussion around the implementation of a socalled "fat tax" (Mason, 2012). Subsidies can be targeted to a small group for a host of reasons: to promote consumption of a particular good over another or if there is a concern that a subsample of the population cannot afford certain goods at full price (for example: Herman, Harrison, Afifi \& Jenks, 2008).

Caraher and Cowburn (2005) offer a policy analysis of the influence food taxes on consumption and behaviour. They find that the impact of taxing foods on obesity is unclear, and argue that taxation alone is not enough to change behaviour (Edwards, 2012; Winkler, 2012). Caraher and Cowburn make a case for using taxes and subsidies together as well as suggesting that policy should additionally target production, manufacturing and advertising.

One kind of food taxation is that of soft drinks or sugar-sweetened beverages (SSB). Calls for SSB taxation are growing as per capita consumption of SSB keeps rising. Over the past three decades, per capita caloric intake from SSB has risen $170 \%$ in the US, with "beverages now account[ing] for 10 to $15 \%$ of the calories consumed by children and adolescents" (Brownell \& Frieden, 2009, pp. 1805-6). Several authors argue that taxing specific foods (such as SSBs) would be an effective way to reduce overweightness (Fletcher, Frisvold \& Tefft, 2010a; 
Andreyeva, Chaloupka \& Brownell, 2011), although the magnitude would be small (Fletcher et al., 2010a). Powell and Chaloupka (2009) find that for either a subsidy or a tax the required price increase must be "non-trivial" in order for the price change to be effective. Substitution effects (due to the availability of many cheap alternatives) have been repeatedly raised as a major concern in regards to this approach (Fletcher, Frisvold \& Tefft, 2010b; Andreyeva et al., 2011; Edward, 2012). Brownell and Frieden (2009) have suggested that an excise tax (a penny-per-ounce of sugar added, rather than a sales tax) might help to address this issue as it prevents consumers from switching to a cheaper brand or a larger size (both of which are cheaper per unit). Furthermore, an excise tax will most likely be passed down to consumers and therefore directly into the shelf price (the price consumers face when making their purchasing decision), rather than a sales tax that is only seen at the till (Brownell \& Frieden, 2009). However, if the substitution effect can be avoided, the tax revenue generated could go toward subsidizing "healthful foods" (Brownell \& Frieden 2009) or toward obesity prevention programs (Andreyeva et al. 2011). Nonetheless, their conclusion is that in order to provide solid policy recommendations about the effectiveness of taxes and subsidies to reduce obesity, further research is necessary (Powell \& Chaloupka 2009, p. 230).

\section{The provision of food in schools}

The literature demonstrates that children who are well-nourished perform better in schools than those who are malnourished (Government of $\mathrm{BC}$, n.d.). As a result there have been programs that offer meals at schools. Traditionally this was done to ensure that children from lower income families had access to nutritious foods. The theory was that by providing meals at school the children would eat healthier. In Canada such initiatives are usually local as there is not a federal or province wide school meal program. However the $\mathrm{BC}$ Ministry of Education does provide CommunityLINK funding to each $\mathrm{BC}$ school district to provide programs and services that "support the 
academic achievement and social functioning of vulnerable students", which can include breakfast, lunch and/or snacks programs (Government of BC, 2014).

The literature on these meal programs is somewhat sparse and contradictory. There are few Canadian studies that look at what children bring to school for lunch. I interpret the literature as suggesting that the socio-economic status of the families at the school may be a larger determinant of whether the lunch provided at school would be better or worse than their own lunch brought from home.

\section{The provision of information in schools}

One of the difficulties in providing advice, not just in schools, but more generally is that information is not always consistent. Different sources can provide a variety of, sometimes contradictory, information. An example of such a contradiction regards one of the many causes of obesity. Whereas Cutler, Glaeser and Shapiro argue that "the rise in obesity involves increased caloric intake, not reduced caloric expenditure" (2003, p. 104), literature provided by Foresight claims the opposite, namely that "it is not increased calories but decreased caloric expenditure that is the problem" (n.d., p. 8). Further, the causes of obesity might not simply be one of these factors but a combination of both. In the United States forty-four of the fifty states require that schools provide health education within the curriculum. Nearly seventy percent of these states include a nutrition and dietary behaviour component. Even so, there is not enough time spent on health education as it competes with teaching the traditional academic curriculum (Story, Kaphingst \& French, 2006).

The BC government created a School Meal and School Nutrition Program Handbook to support schools in feeding students by providing them with well-researched information in a single report. The guidelines "apply to all vending machines, school stores, cafeterias and fundraising sales of food and beverages in the school setting" (n.d., p. 1). This 86-page handbook consists of a wealth of information. But even here recommendations are sometimes unsubstantiated. For 
instance, on page fourteen, while discussing fruits and vegetables, the handbook gives a list of recommended and not recommended foods. It recommends dried fruits but puts banana chips in the category "not to be served". One might think that they might be assuming that banana chips are always sweetened. However, the handbook permits to "choose sometimes" applesauce and/or fruit blends with sugar added.

\section{The debates over monitoring of obesity in schools}

There are two main reasons for measuring BMI in schools (Nihiser, et al., 2007). The first is for surveillance purposes. Surveillance refers to using the data "to identify the percentage of students in a population who are at risk for weight-related problems" (Nihiser et al., 2007, p. 651). This practice is widely accepted. In contrast, measuring BMI in schools for the purpose of screening is rather controversial.

Screening refers to "assess[ing] the weight status of individual students and provid[ing] this information to parents with guidance for action" (Nihiser et al., 2007, p. 651). Nihiser et al. suggest that more research is needed but that there seems to be promising results coming from screening as a way to address childhood obesity. Fayter et al. (2007) also emphasize that there is a lack of data on the potential impact and effectiveness of screening in schools, and that more research is needed. Ikeda, Crawford and Woodward-Lopez (2006) explain that although screening can provide useful information, it can also result in children being labelled as overweight. This can adversely affect these children and result in eating disorders, increased suicide rates, lower self-esteem, depression and social isolation. Furthermore, there is not enough evidence that the monitoring of obesity through BMI or from sending "fat letters" home actually leads to changes in behaviour (Ikeda, Crawford \& Woodward-Lopez, 2006). By contrast the situation is different in Canada. As was recently discussed in Canadian media there is not much public support in Canada for obesity monitoring in schools through BMI (Oved, 2013). Yet Toronto will test 12,000 students this year in grades seven to twelve on a voluntary basis. No "fat letters" will be sent home. Given the 
controversy around BMI screening and its possible adverse effects on children, I preferred not to include weight testing in my research due to possible harm.

Although the above literature review indicates that the findings of studies vary about the effectiveness of taxing "unhealthy" foods and subsidizing "healthy" foods, I include questions in my survey that focus on these particular aspects because I want to know if the cost of food matters for healthy choices as well as what parents actually put in the lunches.

As for the research on provision of food in schools, the literature is more sparse and inconclusive, especially in so far as lunch programs are concerned. I interpret the literature as suggesting that the socio-economic status of the families at the school may be a larger determinant of whether the lunch provided at school would be better or worse than their own lunch brought from home. This article seeks to make a contribution to the above literature by asking what factors impact the choices of parents regarding their children's school lunches.

\section{Methodology}

\section{Study design}

\subsection{Canadian versus US data}

There is some research that studies the impact of food prices (fast food, grocery food or restaurant food) on peoples' behaviour (e.g. Cutler et al., 2003). Most of this literature focuses on US data. I decided to do a pilot study in which I collect my own data, as I could not find any studies using Canadian data. It is also unclear whether US data is representative of the Canadian context. For example, in the US the National School Lunch Program is a federal program that gives all public and not for profit private schools the option to participate for free. Over 100,000 schools participate and provide daily lunches to their students. In Canada, there is no such federal program. For most Canadian students most lunches are packed lunches provided 
by parents. At the school that I surveyed parents are expected to provide a lunch. There is also an optional program organized by the Parents Advisory Council that offers lunches once a month (in this study I will refer to this program as the PAC lunch program). Besides the difference in the scope of lunch programs in the US and Canada, food regulations also differ between them (Government of Canada, 2011).

\subsection{Scope of the survey and sample}

I asked parents what factors they thought influenced them in providing school lunches for their children. In particular my goal was to collect data on what influences parents' decisions in providing fruits and vegetables in school lunches and other similar decisions.

Ideally I would have collected a large sample of responses from parents from a variety of schools that together reflect Canadian socioeconomic average statistics. Due to logistical constraints I surveyed only one school. I verified that the school I selected represents an average income school in Victoria. The median household income in Victoria in 2011 was $\$ 79,350$ (Statistics Canada 2013). The Fraser Institute lists parents' average income in BC schools. The selected school had a median household income between $\$ 50,000-\$ 60,000$ (Fraser Institute 2014). I received permission from the school principal to do an anonymous survey and to coordinate with the secretary of the school to distribute the survey information. The introduction letter with the link to the survey was sent out on January 27, 2014, the two reminders were sent out on January 31, 2014 and February 7, 2014. Therefore support from the school is crucial to success.

\subsection{Why lunches?}

Let us take a step back a minute and look at why I decided to focus my research on lunches rather than for example breakfasts or dinners, which presumably also affect childhood overweight. Looking at these other meals would have been interesting as well, but I chose lunch because it is a meal that is typically not eaten in the presence of parents 
and therefore presumably less controlled than breakfast and dinner. Specifically most days children eat packed lunches at school. On occasion the Parents Advisory Council (PAC) offers school lunches as an option (typically once per month). Studying lunch is attractive because parents face constraints when putting together lunches which may affect healthy choices. These constraints may include: packability of the lunch, children's lack of access to fridges or microwave ovens at school, and time constraints in the morning or night before. Thus, there are fewer options to choose from and therefore it is easier to compare parents' responses.

\subsection{Difficulties}

I implemented two strategies to ensure an as high as possible response rate. The first was to use the term "overweightness" rather than "obesity" to prevent possibly offending participants. Some individuals see the term "obesity" as offensive or derogatory when referring to children. The second action I undertook was on the recommendation of a parent who read the draft of the survey questions. Her advice was to not start the survey with the technical questions. I took her advice and moved them further down the survey, after some of the more straightforward opinion questions.

Research approval from the School Board of School District 61 and approval from the principal of the participating elementary school were required. Although initially I was concerned that a short data collection timeframe (two weeks) would hurt the total number of responses, in hindsight it seems that the response was good. Most people responded within the first week and another peak in responses came when a reminder was sent out a week later. The final reminder (two weeks in) generated just a few responses.

\section{Survey design}

Obesity is now such a widespread epidemic that any child not offered healthy food choices is at risk of gaining excess weight. My goal is to get an insight into what barriers parents face when providing their 
children with nutritious lunches and to learn how parents think in order to understand what drives them to make healthy choices for their children. Parents' food choices reflect barriers and preferences, including cost (both financial and time), knowledge and commitment to children's health. Contrary to others, my survey does not measure obesity or link parents' behaviours to their child(ren)'s actual weight. My survey questions are grouped into seven different themes:

- Parental views on school programs (Q1-Q4)

- Parental views on taxes and subsidies (Q5-Q10)

- Parental views on school lunches (Q12-Q14)

- Parents' leverage over child's lunch consumption (Q15-Q17)

- Parental views on PAC Lunches (Q18-Q21)

- Perceptions on Childhood Overweight (Q22-Q25)

- Demographics (Q28-Q34)

\section{DATA}

\section{Description of data}

The survey got fifty-seven responses. The school that participated had approximately 400 students and fewer parents because there are students with siblings at school. For example, thirty-five percent of survey participants had two children at the school. There are approximately 260 families that could have responded. The response rate therefore is approximately 57/260 or twenty-two percent.

Here are some descriptive statistics of the sample:

- Ninety-one percent of participants were female; nine percent were male.

- Seventy-nine percent of participants were ages 35-44; sixteen percent ages 45-54; and five percent were aged 25-34.

- Eighty-four percent of participants said that all parents worked.

- Seventy percent of participants had children in French immersion (henceforth "French"); twenty-six percent had children in the English stream (henceforth "English"); four percent (two participants) did not answer the question. 
- Approximately two-thirds of the participants' children were in lower grades (Kindergarten-grade 2) and approximately onethird were in the upper grades (grades 3-5).

The broader research project focused on a variety of questions. I will not discuss the responses to the willingness to pay (WTP) questions regarding taxing or subsidizing foods (Q5-Q10) due to space constraints (see Verdun, 2014).

\section{Discussion}

When I analyze the responses to the survey I have in mind a standard microeconomic framework in which parental choices regarding their children's lunches depend on their views ("utility") as well as the restrictions they may face.

Choice $=f($ views, restrictions, controls $)$

Here the "Choice" that is made by parents impacts their children's health. In concrete terms, in the survey these choice variables are found in question Q4 (More focus in curriculum on healthy choices at expense of other programs?), Q5 (Government subsidies of fruits and vegetables?), Q15 (Do you provide fruits and vegetables daily?) and Q21 (Would you pay for healthier PAC lunches?). Depending on the exact "Choice" the "views" include questions Q22, Q23 and Q24 (perceptions of childhood overweight in school, province, and family). The "restrictions" include child refusal, prep time, peer pressure, and cost. The "controls" are the demographic questions Q28-Q34 (gender, age, number of 19+ adults, if all parents work, number of children, how many attend selected school, and grades of children at selected school). Due to my small sample, fifty-seven observations, I decided not to do econometrics. If I had had more observations the above framework depicts what I would have done. However, the remainder of my discussion is based on the above microeconomic framework. 


\section{Health education and physical activity in schools (Q1-Q4)}

From both surveys it is clear that although the majority of parents support providing health education and infrastructure for physical activities (recess and intramurals) they do not want it at the expense of time for the traditional academic curriculum. This finding has policy implications. Some of these include not reducing time spent providing health education and physical activity infrastructure. Furthermore, if there is an interest in increasing these provisions, it should not come at the expense of the time to teach traditional academic curriculum. An alterative to that reduction in current curriculum time is to increase the total hours of school in a week, allowing for both types of curriculum (including more time for physical activities) to be taught.

With more observations I would have regressed the choice variable Q4 (support for school programs even at the cost of reduced traditional curriculum) on the relevant view variable Q23 (perceptions of childhood overweight in the school), and with Q28-Q34 being the control variables. (There are no "restrictions" in this context). However due to my small sample I instead looked at the tentative relationship between Q4 and Q23. The correlation between these two variables was positive and significant at the ten percent level. An arguably more informative way to sketch the relationship between Q4 and Q23 is found in Figure 1.

The figure also shows the positive relationship between $\mathrm{Q} 4$ and Q23. This can be seen by noticing that as agreement to Q4 increases from left to right along the horizontal axis, so does agreement increase for Q23 (the green part) and disagreement decrease for Q23 (the red part) along the vertical axis. As parents perceive childhood overweight in the school to be a more serious issue there is more support by parents for the school program. 


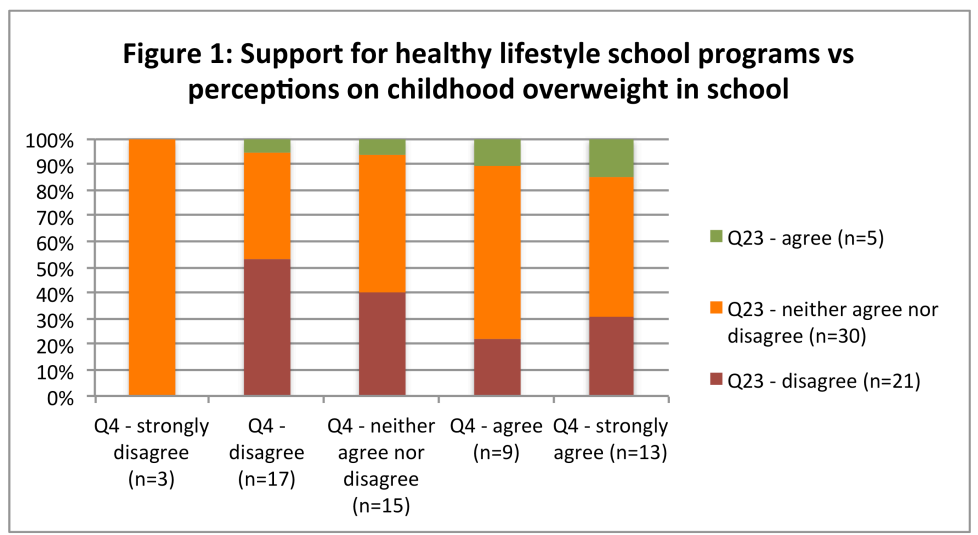

2. Possible factors for why some children do not bring fruits and vegetables to school every day (Q12-Q17)

All participants broadly agreed with the survey question regarding whether children should ideally bring fruits and vegetables to school in their lunches everyday. This unanimity did not surprise me. However, when asked if this was a reality for their child(ren) only eightyfour percent of participants broadly agreed. If the parents did not broadly agree I asked them what were possible factors for why they did not provide their child(ren) fruits and vegetables in their lunch every day. By far the most selected answer (i.e. eighty-five percent of participants) was the refusal by the children to eat them. Then came the problem of too a high a preparation time (twenty-three percent), then peer pressure of alternatives being deemed "cooler" (fifteen percent) and finally cost being too excessive was selected by just one participant (eight percent).

These findings suggest that at least for this school the cost of fruits and vegetables for most parents is not a barrier to putting them in lunches everyday. For most parents who do not put fruits and vegetables in the lunch every day it is the fact that children refuse to eat them, which could be due to a lack of leverage. What is noticeable is that as parents face restrictions (Q16) they are less likely to provide 
Figure 2: Parents who face restrictions more often do not include fruits and vegetables daily in school lunch

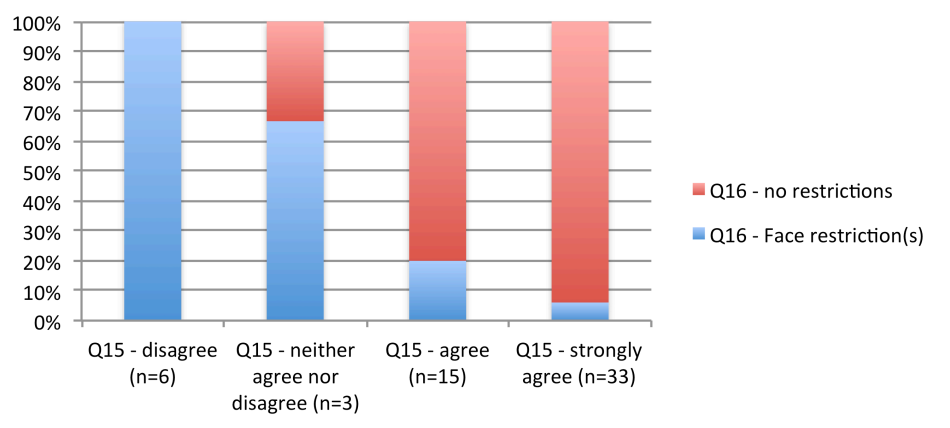

fruits and vegetables in their child's lunch everyday (Q15) (Figure 2). The fact that price is for most parents not a restriction suggests that for schools with many families at this income level a subsidy, although possibly effective in encouraging parents to buy more fruits and vegetables, may not induce those last families to provide fruits and vegetables in the lunches everyday, as price is not the problem. How to encourage children to eat them is a whole other problem, which a taxation or subsidy type policy may not be able to address (That said, if a school with a fair number of low-income families had been surveyed, a subsidy may have assisted the parents in providing their child(ren) with fruits and vegetables in their lunch daily). However, it could possibly be addressed by providing children more time to eat. As one participant mentioned:

What I find is the problem is that children are not given enough time to eat their lunches and therefore parents have to resort to pre-packaged foods and when a child is given 10 minutes to eat lunch, they will eat the 'treats' first and leave the veggies and healthy choices for last. If lunchtime was increased to 30 minutes ... I believe that we would see better eating habits and healthier kids. 
Time to eat lunch, or lack thereof, seems to be another constraint that influences what parents put in their child(ren)'s lunches (not just in regard to fruits and vegetables), that was mentioned by several parents in the comments section of the survey. As a result of this short lunch break, some parents choose to pack a lunch that is quick to eat. Similarly, a different participant mentioned that:

The foods given in lunches is restricted by the short time in which children are allowed to eat, therefore options like soup or something that takes more time to eat are eliminated. 'Snacks' become the primary focus.

The assumption was that if there is one homemaker, he or she might have more time dedicated to making the lunch. The difference between such a family and the "all parents working" family could be hypothesized as making a difference in what lunches the children bring to school. For example a homemaker might have more time to spend on making lunches and buying designated lunch ingredients. In my survey only sixteen percent of participants had a designated homemaker within the family. I checked the results on a few survey questions (Q5, Q13, Q15 and Q17) where I had hypothesized there might have been a difference in responses, but could not find significant differences between the two groups. This result may not be as meaningful as the sixteen percent of participants represents only nine participants.

In summary, although eighty-four percent of all participants indicate that they put fruits and vegetables in school lunches everyday, those who do not list as a reason that children do not eat the fruits and vegetables. This refusal may be due to a lack of leverage. Presumably participants do not want the produce to go to waste. Some participants suggested that increasing the time for children to eat their lunch might increase the likelihood of them eating (more) fruits and vegetables. 


\section{PAC lunches (Q18-Q21)}

Several participants expressed that they view the school Parent Advisory Council (PAC) lunches as treats or not very healthy. They expressed an interest for increased healthy options. There is also high participation (ninety-one percent) among the participants with regards to the PAC lunches, even though eighty-three percent of these participants find their own lunches healthier than the PAC's lunches. Seventy-three percent of survey participants, not just the PAC lunch participants, broadly agreed that they would be willing to pay an additional $\$ 0.50$ per lunch, so that the PAC lunches always include an extra serving of fruits or vegetables. Participants in the survey do not consider the PAC lunches very healthy. As an economist this result is noteworthy because PAC lunches are provided as a way for the PAC to fundraise, not necessarily as a way to provide children with healthy meals. Some of the current lunches provided include Subway sandwiches and Booster Juice with pizza. The PAC meets its objectives of fundraising, but does not necessarily meet the desires of the parents/guardians for healthy lunches.

Again due to a lack of observations, I did not regress the choice variable Q21 (support for making the PAC lunches healthier) on the view variable Q24 (perceptions of childhood overweight as a big issue in the respondent's family) with Q28-Q34 being the control variables. (There are no "restrictions" in this context). But looking at the relationship between Q21 and Q24 I do find a negative relationship (Figure 3), which can also be found when looking at correlations, however it is not statistically significant.

As parents more strongly perceive childhood overweight to be an issue in their family they are less supportive of making PAC lunches healthier. In other words, as parents perceive childhood overweight to be less of a concern in their family they tend to support more strongly making the PAC lunches healthier for a slight rise in PAC lunch cost. 


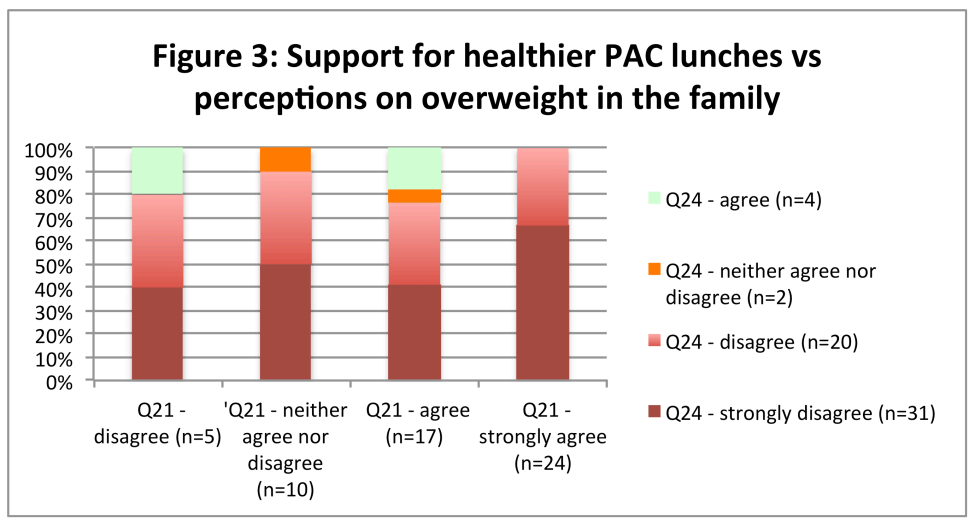

4. Perceptions of parents regarding percentage of children who have an unhealthy excess weight (Q22-Q25)

When looking at parents' perceptions of childhood overweight as an issue in British Columbia, in the school and in the home there is a noticeable pattern. As the issue of childhood overweight gets closer to home, parents tend to report childhood overweight as not being a big issue. When asking about the provincial level seventy-nine percent of parents indicated that childhood overweight was a big issue. When asking about the school level nine percent indicated it was a big issue, with forty percent indicating it was not a big issue. In contrast, when asking their perceptions about their own household seven percent indicated it was a big issue, but eighty-nine percent said it was not. The key point to take away is that at the provincial level many of the parents indicated childhood overweight is a big issue, at the school level many parents are unsure and at the household level the large majority of parents indicate it is not a big issue (Table 1). 
Table 1: Q22-24 broken down into three response categories

\begin{tabular}{llll} 
& $\begin{array}{l}\text { Broadly } \\
\text { agree }\end{array}$ & $\begin{array}{l}\text { Broadly } \\
\text { disagree }\end{array}$ & $\begin{array}{l}\text { Neither agree } \\
\text { nor disagree }\end{array}$ \\
\hline Q22 (BC) & $79 \%$ & $0 \%$ & $21 \%$ \\
Q23 (School) & $9 \%$ & $39 \%$ & $51 \%$ \\
Q24 (Home) & $7 \%$ & $89 \%$ & $4 \%$ \\
\hline
\end{tabular}

When asked "what percentage of children do you think have an unhealthy excess weight in Canada today?" eighty-one percent of participants chose either the correct bracketed answer (25-34\%) or the bracketed answer just above (35-44\%) or below (15-24\%) the correct one, but only twenty-eight percent chose the correct bracketed answer (Statistics Canada in 2007 calculated the correct answer to be twenty-nine percent [Child Obesity Foundation, n.d]). It seems that the participants have a fairly decent understanding of the magnitude of childhood obesity as only nineteen percent of participants picked bracketed answers that were far from the correct one.

One model I considered was that participants that had underestimated the percentage of children in Canada with excess weight (Q25) would be less supportive of excess weight reducing policies, such as willing to trade-off traditional curriculum for nutrition education and provision of physical activities (Q4), willingness to subsidize fruits and vegetables (Q5) and willingness to pay more for healthier PAC lunches (Q21). Similarly, those who overestimated the percentage of children in Canada with excess weight (Q25) would be more supportive of such policies. Using a regression and holding constant key demographics (gender, whether the participant's children were in French or English and the number of children in the participant's family) I found no statistically significant relationship between a participant's perception of the percentage of children in Canada with excess weight and the participant's support for the three policies mentioned. 


\section{Limitations}

One of the limitations is the small sample size of the data. It makes generalizing the results difficult. The small sample size also meant that frequently I could not divide the data into meaningful subsets. Many of the attributes did not have enough observations, once split into groups, to be able to make reliable conclusions. As well, this study only reported those parents that participated in the survey. It is possible that these participants are those who are most engaged in this issue. Therefore they would show more awareness than is representative for the whole population. As a consequence, the results may reflect the parents' intentions and may not necessarily represent the parents' actual behaviour.

\section{Conclusion}

This article has focused on the food quality dimension of childhood obesity, in particular the factors that impact the choices of parents regarding their children's school lunches. By conducting a survey at an elementary school I was able to create a dataset of fifty-seven responses, study correlations among numerous variables and provide some insights using a more qualitative approach. One of the aims was to draw conclusions from this dataset that could be compared to results in other studies. I find that compared to Evans et al. (2005) the parents in my dataset are more willing to support teaching children in school about healthy eating and exercise habits. They are also more willing to support these school programs even if it means a reduction in hours spent on teaching the traditional curriculum.

The three tentative correlations I found were: (1) as parents perceive childhood overweight in the school to be a more serious issue there is more support by parents for the school program on teaching children healthy eating and exercise habits as well as providing physical activities; (2) as parents face restrictions they are less likely to provide fruits and vegetables in their child's lunch everyday; and (3) as parents more strongly perceive childhood overweight to be an issue in their family they are less supportive of making PAC lunches 
healthier.

Contrary to my initial predictions, I found that parents perceive price not to be a major factor in determining whether or not parents include fruits and vegetables in their child(ren)'s school lunch. In fact, the reason provided most frequently by parents not to include the fruits and vegetables was that the child(ren) did not eat them (suggesting a possible lack of leverage of the parents on what the children eat), followed by too high a preparation time. Some participants explained that for some children the fruits and vegetables were not eaten due to a shortage of time to eat during the lunch break. They recommended increasing the duration of the eating portion of the lunch break (the other portion is for the children to play outside). Participants also mentioned that due to the short eating portion of the lunch break many feel they cannot provide a slower and typically healthier lunch, such as soup, but must instead provide more "snack" like foods. One policy suggestion would be to consider increasing the time allowed for school children to eat their lunch.

Furthermore, price was not a constraint as participants indicated willingness to pay more for the PAC provided lunches to be healthier. Several participants mentioned they viewed the current PAC lunches as "treats." Therefore the PAC could consider providing healthier lunches even if at a higher cost to parents. I found that participants are quite aware of the seriousness of childhood obesity and the importance of providing a healthy lunch; participants also make a serious effort to provide one. There is unanimous support among parents for having schools be involved in teaching healthy eating and exercise habits. However, not all parents support this at the expense of the currently taught traditional academic curriculum. As a policy recommendation I would suggest adding hours, not replacing them, if there is a desire to provide more information about nutrition and exercise in schools.

There was an interesting observation about the data concerning parents of children in the French immersion and the English stream. The responses of parents of the former showed a significant relationship between support for subsidizing fruits and vegetables and sup- 
port for paying more for healthier school lunches. By contrast, there was no significant relationship among the English stream parents. As mentioned above, more research is needed to explore the reasons for this difference.

I started off doing this research believing that to understand the obesity problem better one could focus on food consumption. School lunches seemed a good way to narrow down the study of meals consumed by children. I was particularly keen to learn about the role of parents in this process. I thought that if obesity was a widespread problem we should be able to see this issue reflected in parents' views. My research has shown that many parents are aware of the problem. From economics we learn that price plays an important role in determining what people buy. This research shows that on the whole parents are willing to pay more for healthy lunches. In fact, if left on their own they would typically provide fruits and vegetables in their child(ren)'s school lunches every day.

The present study was based on a pilot study of one school, a next step could be to study more schools. Furthermore, additional research would be needed to investigate the parents who did not participate in my study to make sure there is not some kind of bias in the sample of parents I have researched. Moreover, this particular research method may have the problem that there might be a discrepancy between what participants declare and what they actually do. Therefore further research would also need to take this possible discrepancy into account. 


\section{REFERENCES}

Andreyeva, T., Chaloupka, F.J., \& Brownell, K.D. (2011). Estimating the potential of taxes on sugar-sweetened beverages to reduce consumption and generate revenue. Preventative Medicine, 52(6), 413-416. http://dx.doi.org/10.1016/j.ypmed.2011.03.013

Brownell, K.D., \& Frieden, T.R. (2009). Ounces of prevention - The public policy case for taxes on sugared beverages. The New England fournal of Medicine, 360(18), 1805-1808. $\begin{gathered}\text { http://dx.doi.org/10.1056/ } \\ \text { nejmp0002392 }\end{gathered}$

Caraher, M., \& Cowburn, G. (2005). Taxing food: implications for http://dx.doi.org/ public health nutrition. Public Health Nutrition, 8(8), 1242-1249, 10.1079/phn20

Centre for Science in the Public Interest. (2009). Backgrounder: A national nutritious school meal program for Canadian children. Retrieved March 27, 2014, from http://cspinet.org/canada/pdf/childnutrition-backgrounder-jan2009-budget.pdf

Child Obesity Foundation. (n.d.). Statistics. Retrieved February 20, 2014, from http://www.childhoodobesityfoundation.ca/statistics

Cutler, D.M., Glaeser, E.L., \& Shapiro, J.M. (2003). Why have Americans become more obese? The fournal of Economic Perspectives, 17(3), 93-118. http://dx.doi.org/10.1257/089533003769204371

Edwards, R.D. (2012). Sugar-sweetened beverage taxes raise demand for substitutes and could even raise caloric intake. Preventative Medicine, 54(3-4), 284-285. http://dx.doi.org/10.1016/j.ypmed.2011.12.003

Evans, W.D., Finkelstein, E.A., Kamerow, D.B., \& Renaud, J.M. (2005). Public perceptions of childhood obesity. American fournal of Preventive Medicine, 28(1), 26-32. http://dx.doi.org/10.1016/j.amepre.2004.09.008

Fayter D., Nixon, J., Hartley, S., Rithalia, A., Butler, G., Rudolf, M., \& Westwood, M. (2007). A systematic review of the routine monitoring of growth in children of primary school age to identify growth-related conditions. Health Technology Assessment, 11(22), 1-184. http://dx.doi.org/10.3310/hta1 1220

Fletcher, J.M., Frisvold, D.E., \& Tefft, N. (2010a). Can soft drink taxes reduce population weight? Contemporary Economic Policy, 28(1), 23-35. http://dx.doi.org/10.1111/j.1465-7287.2009.00182.x

Fletcher, J.M., Frisvold, D.E. \& Tefft, N. (2010b). The effects of soft 
drink taxes on child and adolescent consumption and weight outcomes. Fournal of Public Economics, 94(11-12), 967-974. ${ }^{\text {http:///dx.doi.org/10.1016 }}$

Foresight. (n.d.). Trends and drivers of obesity: A literature review for the Foresight project on obesity. Retrieved February 6, 2014, from http://www.bis.gov.uk/assets/foresight/docs/obesity/litera ture_review.pdf

Fraser Institute. (2014). Comparing academic rankings and ratings of British Columbia schools. http://britishcolumbia. compareschoolrankings.org/elementary/SchoolsByRankLocationName.aspx

Gleason, P.M., \& Dodd, A.H. (2009). School breakfast program but not school lunch program participation is associated with lower body mass index. Journal of the American Dietetic Association, Supplement, 109(2), 118-128. http://dx.doi.org/10.1016/j.jada.2008.10.058 Government of Canada. (2011). Joint action plan for the CanadaUnited States regulatory cooperation council. Retrieved April 18, 2014, from http://actionplan.gc.ca/sites/default/files/japlan_eng. pdf

Government of British Columbia. (n.d.). School meal and school nutrition program handbook. Retrieved February 13, 2014, from http://www.bced.gov.bc.ca/communitylink/pdf/smph.pdf

He. (2007). Are parents aware that their children are overweight or obese?. Cam Fam Physicians, 53(9), 1493-1499.

Herman, D.R., Harrison, G.G., Afifi, A.A., \& Jenks, E. (2008). Effect of a targeted subsidy on intake of fruits and vegetables among low-income women in the Special Supplemental Nutrition program for women, infants, and children. American fournal of Public Health, 98(1), 98-105. http://dx.doi.org/10.2105/ajph.2005.079418

Ikeda, J.P., Crawford, P.B., \& Woodward-Lopez, G. (2006). BMI screening in schools: Helpful or harmful. Health Education Research, 21(6), 761-769. http://dx.doi.org/10.1093/her/cyl144

Macmillan Dictionary. (2014). Obesity. In macmillandictionary.com. Retrieved February 6, 2014, from http://www.macmillandictionary. com/dictionary/british/obesity

Mason, C. (2012). Fat tax would benefit Kiwis - study. The New Zealand Herald. Retrieved March 24, 2014, from http://www.nz 
herald.co.nz/lifestyle/news/article.cfm?c_id=6\&objectid=10853536 Millimet, D.L., Tchernis, R., \& Husain, M. (2010). School nutrition programs and the incidence of childhood obesity. The fournal of Human Resources, 48(3), 640-654. http://dx.doi.org/10.1353/jhr.2010.0021 Nihiser, A.J., Lee, S.M., Wechsler, H., McKenna, M., Odom, E., Reinold, C., \& Grummer-Strawn, L. (2007). Body mass measurement in schools. Fournal of School Health, 77(10), 651-671. hitp://dx.doi.org/10.1111// Oved, M.C. (2013). Toronto schools won't send "fat letters" home. The Toronto Star (August 19, 2013). Retrieved March 9, 2014, from http://www.thestar.com/life/health_wellness/2013/08/19/toronto_ schools_to_measure_students_weight_but_wont_send_fat_letters home.html

Powell, L.M., \& Chaloupka, F.J. (2009). Food prices and obesity: Evidence and policy implications for taxes and subsidies. Milbank Quarterly, 87(1), 229-257. http://dx.doi.org/10.1111/j.1468-0009.2009.00554.x Statistics Canada. (2013). Median total income, by family type, by census metropolitan area. Retrieved February 22, 2014, from http:// www.statcan.gc.ca/tables-tableaux/sum-som/101/cst01/famil107aeng.htm

Story, M., Kaphingst, K.M., \& French, S. (2006). The role of schools in

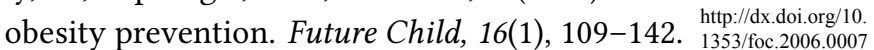

Verdun, Z. (2014). Parental views on school lunches: An insight into childhood overweight. University of Victoria, Department of Economics, unpublished Honours thesis.

WHO. (2013). Growth reference 5-19 years. Retrieved November 13, 2013, from http://www.who.int/growthref/who2007_bmi_for_age /en/index.html

Winkler, J.T. (2012). Why soft drink taxes will not work. British fournal of Nutrition, 108(3), 395-396. http://dx.doi.org/10.1017/s0007114511006477

\section{ApPENDiXes}

\section{Appendix A1}




\section{List of Questions for Survey "Parental perceptions on nutritious school lunches"}

\begin{tabular}{|c|c|c|}
\hline Number & Question & Type \\
\hline $\begin{array}{l}\text { Question } \\
1\end{array}$ & $\begin{array}{l}\text { I support my school teaching students healthy } \\
\text { eating and exercise habits. }\end{array}$ & $\begin{array}{l}\text { Likert Scale } \\
\text { Type the answer options here, } \\
\text { separated by semi-colons }\end{array}$ \\
\hline $\begin{array}{l}\text { Question } \\
2\end{array}$ & $\begin{array}{l}\text { I support the Daily Physical Activity (DPA) program } \\
\text { and physical education classes in school. }\end{array}$ & $\begin{array}{l}\text { Likert Scale } \\
\text { Type the answer options here, } \\
\text { separated by semi-colons }\end{array}$ \\
\hline $\begin{array}{l}\text { Question } \\
3\end{array}$ & $\begin{array}{l}\text { I support recess and supervised intramural } \\
\text { activities in school. }\end{array}$ & $\begin{array}{l}\text { Likert Scale } \\
\text { Type the answer options here, } \\
\text { separated by semi-colons }\end{array}$ \\
\hline $\begin{array}{l}\text { Question } \\
4\end{array}$ & $\begin{array}{l}\text { I would favour directing more time in the school } \\
\text { curriculum towards school teaching students } \\
\text { healthy eating and exercise habits and DPA if it } \\
\text { meant less time for traditional academic courses } \\
\text { such as math, science, English, and social studies. }\end{array}$ & $\begin{array}{l}\text { Likert Scale } \\
\text { Type the answer options here, } \\
\text { separated by semi-colons }\end{array}$ \\
\hline $\begin{array}{l}\text { Question } \\
5\end{array}$ & $\begin{array}{l}\text { If the government proposed subsidizing fruits and } \\
\text { vegetables, reducing their price by } 10 \% \text { but } \\
\text { increased my household's income tax by } \$ 100 \text { per } \\
\text { year, I would support this proposal. }\end{array}$ & $\begin{array}{l}\text { Likert Scale } \\
\text { Type the answer options here, } \\
\text { separated by semi-colons }\end{array}$ \\
\hline $\begin{array}{l}\text { Question } \\
6\end{array}$ & $\begin{array}{l}\text { (Answer this question if you disagreed with } \\
\text { question } 5 \text {, otherwise skip to the next question): I } \\
\text { would support subsidizing fruits and vegetables, } \\
\text { reducing their price by } 10 \% \text { but increasing my } \\
\text { household's income tax by } \$ 50 \text { per year? }\end{array}$ & $\begin{array}{l}\text { Likert Scale } \\
\text { Type the answer options here, } \\
\text { separated by semi-colons }\end{array}$ \\
\hline $\begin{array}{l}\text { Question } \\
7\end{array}$ & $\begin{array}{l}\text { (Answer this question if you agreed with question } 5 \text {, } \\
\text { otherwise skip it): I would support subsidizing fruits } \\
\text { and vegetables, reducing their price by } 10 \% \text { but } \\
\text { increasing my household's income tax by } \$ 200 \text { per } \\
\text { year? }\end{array}$ & $\begin{array}{l}\text { Likert Scale } \\
\text { Type the answer options here, } \\
\text { separated by semi-colons }\end{array}$ \\
\hline $\begin{array}{l}\text { Question } \\
8\end{array}$ & $\begin{array}{l}\text { If the government proposed taxing soda and other } \\
\text { sugared beverages by } 10 \% \text {, and reduced my } \\
\text { household's income taxes by } \$ 25 \text { per year, I would } \\
\text { support this proposal. }\end{array}$ & $\begin{array}{l}\text { Likert Scale } \\
\text { Type the answer options here, } \\
\text { separated by semi-colons }\end{array}$ \\
\hline $\begin{array}{l}\text { Question } \\
9\end{array}$ & $\begin{array}{l}\text { (Answer this question if you disagreed with } \\
\text { question } 8 \text {, otherwise skip to the next question): I } \\
\text { would support the tax on soda if my household's } \\
\text { income taxes were also reduced by } \$ 50 \text {. }\end{array}$ & $\begin{array}{l}\text { Likert Scale } \\
\text { Type the answer options here, } \\
\text { separated by semi-colons }\end{array}$ \\
\hline $\begin{array}{l}\text { Question } \\
10\end{array}$ & $\begin{array}{l}\text { (Answer this question if you agreed with question } 8 \text {, } \\
\text { otherwise skip it): I would support the tax on soda } \\
\text { if my household's income taxes did not change. }\end{array}$ & $\begin{array}{l}\text { Likert Scale } \\
\text { Type the answer options here, } \\
\text { separated by semi-colons }\end{array}$ \\
\hline $\begin{array}{l}\text { Question } \\
11\end{array}$ & $\begin{array}{l}\text { Now the questions will focus on your child's school } \\
\text { lunch. }\end{array}$ & $\begin{array}{l}\text { Insert a statement that does not } \\
\text { require an answer } \\
\text { Type the answer options here, } \\
\text { separated by semi-colons }\end{array}$ \\
\hline $\begin{array}{l}\text { Question } \\
12\end{array}$ & $\begin{array}{l}\text { I always ensure my child takes a nutritious lunch to } \\
\text { school. }\end{array}$ & $\begin{array}{l}\text { Likert Scale } \\
\text { Type the answer options here, }\end{array}$ \\
\hline
\end{tabular}




\begin{tabular}{|c|c|c|}
\hline $\begin{array}{l}\text { Question } \\
13\end{array}$ & I feel confident I know what a nutritious lunch is. & $\begin{array}{l}\text { Likert Scale } \\
\text { Type the answer options here, } \\
\text { separated by semi-colons }\end{array}$ \\
\hline $\begin{array}{l}\text { Question } \\
14\end{array}$ & $\begin{array}{l}\text { Ideally my child(ren) should have fruits or } \\
\text { vegetables in their lunch every day. }\end{array}$ & $\begin{array}{l}\text { Likert Scale } \\
\text { Type the answer options here, } \\
\text { separated by semi-colons }\end{array}$ \\
\hline $\begin{array}{l}\text { Question } \\
15\end{array}$ & $\begin{array}{l}\text { My child(ren) bring(s) fresh fruits and vegetables } \\
\text { to school every day. }\end{array}$ & $\begin{array}{l}\text { Likert Scale } \\
\text { Type the answer options here, } \\
\text { separated by semi-colons }\end{array}$ \\
\hline $\begin{array}{l}\text { Question } \\
16\end{array}$ & $\begin{array}{l}\text { If disagree with the previous question, what are } \\
\text { some of the restrictions? (choose all that apply) }\end{array}$ & $\begin{array}{l}\text { Multiple Checkbox } \\
\text { Cost is excessive; Preparation time is } \\
\text { too high (not convenient); Child } \\
\text { refuses to eat them; Peer pressures } \\
\text { (e.g. fruits and vegetables are } \\
\text { deemed 'less cool' than alternatives) }\end{array}$ \\
\hline $\begin{array}{l}\text { Question } \\
17\end{array}$ & $\begin{array}{l}\text { In our household lunch is made in consultation } \\
\text { with my child. }\end{array}$ & $\begin{array}{l}\text { Likert Scale } \\
\text { Type the answer options here, } \\
\text { separated by semi-colons }\end{array}$ \\
\hline $\begin{array}{l}\text { Question } \\
18\end{array}$ & $\begin{array}{l}\text { My child(ren) participate(s) in the Parent Advisory } \\
\text { Council (PAC) lunch program. }\end{array}$ & $\begin{array}{l}\text { Likert Scale } \\
\text { Type the answer options here, } \\
\text { separated by semi-colons }\end{array}$ \\
\hline $\begin{array}{l}\text { Question } \\
19\end{array}$ & $\begin{array}{l}\text { I find my own homemade lunches are more } \\
\text { nutritious than the PAC's lunch program options } \\
\text { that I (would) choose. }\end{array}$ & $\begin{array}{l}\text { Likert Scale } \\
\text { Type the answer options here, } \\
\text { separated by semi-colons }\end{array}$ \\
\hline $\begin{array}{l}\text { Question } \\
20\end{array}$ & $\begin{array}{l}\text { I always choose the most healthy lunch options of } \\
\text { the PAC's lunch program. }\end{array}$ & $\begin{array}{l}\text { Likert Scale } \\
\text { Type the answer options here, } \\
\text { separated by semi-colons }\end{array}$ \\
\hline $\begin{array}{l}\text { Question } \\
21\end{array}$ & $\begin{array}{l}\text { I would be willing to pay an additional } \$ 0.50 \text { per } \\
\text { lunch, so that PAC lunches always include an extra } \\
\text { serving of fruits or vegetables. }\end{array}$ & $\begin{array}{l}\text { Likert Scale } \\
\text { Type the answer options here, } \\
\text { separated by semi-colons }\end{array}$ \\
\hline $\begin{array}{l}\text { Question } \\
22\end{array}$ & $\begin{array}{l}\text { Childhood overweightness is a major issue in } \\
\text { British Columbia. }\end{array}$ & $\begin{array}{l}\text { Likert Scale } \\
\text { Type the answer options here, } \\
\text { separated by semi-colons }\end{array}$ \\
\hline $\begin{array}{l}\text { Question } \\
23\end{array}$ & $\begin{array}{l}\text { Childhood overweightness is a major issue in my } \\
\text { child's school. }\end{array}$ & $\begin{array}{l}\text { Likert Scale } \\
\text { Type the answer options here, } \\
\text { separated by semi-colons }\end{array}$ \\
\hline $\begin{array}{l}\text { Question } \\
24\end{array}$ & $\begin{array}{l}\text { Childhood overweightness is a major issue in my } \\
\text { family. }\end{array}$ & $\begin{array}{l}\text { Likert Scale } \\
\text { Type the answer options here, } \\
\text { separated by semi-colons }\end{array}$ \\
\hline $\begin{array}{l}\text { Question } \\
25\end{array}$ & $\begin{array}{l}\text { What percentage of children do you think have an } \\
\text { unhealthy excess weight in Canada today? (select } \\
\text { one) }\end{array}$ & $\begin{array}{l}\text { Multiple Choice } \\
\text { <5\%; 5-14\%; } 15-24 \% ; 25-34 \% ; 35- \\
44 \% ; 45-54 \% ; 55-64 \% ; 65-74 \% \\
75-84 \% ; 85-94 \% ;>95 \%\end{array}$ \\
\hline $\begin{array}{l}\text { Question } \\
26\end{array}$ & $\begin{array}{l}\text { (optional) Please provide an example of your } \\
\text { child's typical school lunch? }\end{array}$ & $\begin{array}{l}\text { Long Answer } \\
\text { Type the answer options here, } \\
\text { separated by semi-colons }\end{array}$ \\
\hline
\end{tabular}




\begin{tabular}{|c|c|c|}
\hline $\begin{array}{l}\text { Question } \\
27\end{array}$ & $\begin{array}{l}\text { If you feel comfortable could you please answer the } \\
\text { following questions }\end{array}$ & $\begin{array}{l}\text { Insert a statement that does not } \\
\text { require an answer } \\
\text { Type the answer options here, } \\
\text { separated by semi-colons }\end{array}$ \\
\hline $\begin{array}{l}\text { Question } \\
28\end{array}$ & Gender & $\begin{array}{l}\text { Multiple Choice } \\
\text { Male;Female;Other; Prefer not to } \\
\text { answer }\end{array}$ \\
\hline $\begin{array}{l}\text { Question } \\
29\end{array}$ & Age & $\begin{array}{l}\text { Multiple Choice } \\
\begin{array}{l}20-24 ; 25-34 ; 35-44 ; 45-54 ; 55-64 ; \\
65+; \text { Prefer not to answer }\end{array}\end{array}$ \\
\hline $\begin{array}{l}\text { Question } \\
30\end{array}$ & $\begin{array}{l}\text { Number of individuals in your household who are } 19 \\
\text { years or older? }\end{array}$ & $\begin{array}{l}\text { Multiple Choice } \\
1 ; 2 ; 3 ; 4+; \text { Prefer not to answer }\end{array}$ \\
\hline $\begin{array}{l}\text { Question } \\
31\end{array}$ & Do all parents/guardians work? & $\begin{array}{l}\text { Multiple Choice } \\
\text { yes;no;Prefer not to answer }\end{array}$ \\
\hline $\begin{array}{l}\text { Question } \\
32\end{array}$ & Number of children in the household? & $\begin{array}{l}\text { Multiple Choice } \\
1 ; 2 ; 3 ; 4 ; 5+; \text { Prefer not to answer }\end{array}$ \\
\hline $\begin{array}{l}\text { Question } \\
33\end{array}$ & $\begin{array}{l}\text { How many of these children go to } \\
\text { Elementary School? }\end{array}$ & $\begin{array}{l}\text { Multiple Choice } \\
1 ; 2 ; 3 ; 4 ; 5+\end{array}$ \\
\hline $\begin{array}{l}\text { Question } \\
34\end{array}$ & What grades are they in? (choose all that apply) & $\begin{array}{l}\text { Multiple Checkbox } \\
\text { K - English;1 - English;2 - English;3 } \\
\text { - English;4 - English;5 - English;K - } \\
\text { French;1 - French;2 - French;3 - } \\
\text { French;4 - French;5 - French }\end{array}$ \\
\hline $\begin{array}{l}\text { Question } \\
35\end{array}$ & Any other comments or feedback? & $\begin{array}{l}\text { Long Answer } \\
\text { Type the answer options here, } \\
\text { separated by semi-colons }\end{array}$ \\
\hline $\begin{array}{l}\text { Question } \\
36\end{array}$ & Thank you very much for your participation. & $\begin{array}{l}\text { Insert a statement that does not } \\
\text { require an answer } \\
\text { Type the answer options here, } \\
\text { separated by semi-colons }\end{array}$ \\
\hline
\end{tabular}

